\title{
Analiza načina medijskog izvještavanja hrvatskih internetskih portala o koronavirusu
}

Stručni rad, DOI 10.22522/cmr20210167, primljeno 15. svibnja 2021.

UDK : $\quad 316.774(047.6): 616-036.22$

$004.738: 070.18$

$004.775: 070.18$

\section{Medina Benzinović (studentica)}

Sveučilište Vern', Zagreb, Hrvatska.

\section{dr. sc. Krešimir Dabo (kontakt osoba)}

Edward Bernays University College, Zagreb, Hrvatska.

E-adresa: kresimir.dabo@bernays.hr

\section{Helena Šimić}

Edward Bernays University College, Zagreb, Hrvatska.

E-adresa: helena.simic@bernays.hr

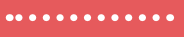

\section{Sažetak}

Pojava epidemije koronavirusa promijenila je način na koji su mediji izvještavali svoje čitatelje u svijetu, pa tako i u Hrvatskoj. Bilo koja vijest se predstavljala kao glavna vijest pri čemu su se takvim sadržajima najviše isticali internetski portali. Intenzivno širenje informacija dovelo je do izrazito velikog broja senzacionalističkih naslova, ali i do dezinformacija u obliku tzv. lažnih vijesti. Cilj rada bio je utvrditi način medijskog izvještavanja o epidemiji u Hrvatskoj, ponuditi teorijski okvir vezan uz tu temu, ispitati percepciju i svjesnost čitatelja o fenomenu dezinformacija uz dodatnu analizu sadržaja najčitanijih medijskih portala.

Ključne riječi: medijsko izvještavanje, internetski portali, društvene mreže, lažne vijesti, koronavirus 


\section{Uvod}

Odnosi s javnošću profesija su koja se može povezati s brojnim različitim područjima. Riječ je o komunikaciji u kojoj su mediji često najvažniji čimbenik. Posljednjih godina posebnu ulogu imaju digitalni mediji i društvene mreže putem kojih javnost na najbrži i najlakši način dolazi do informacija iz cijeloga svijeta te iz minute $u$ minutu može pratiti novosti i ostale sadržaje. Iako konvencionalni mediji i dalje imaju značajan utjecaj na javnost, odnosno moć u oblikovanju mišljenja, društvene mreže i digitalni sadržaji danas preuzimaju komunikacijsku dominaciju. Digitalni alati dostupni su svima, a zahvaljujući njima svatko može objaviti i dijeliti sadržaj. Jedna od negativnih posljedica toga je sve veći broj neistinitih informacija kojima se nerijetko zastrašuje javnost ili jednostavno privlači pozornost, ovisno o cilju i namjeri komunikatora. Stoga nije neobično što se kao rezultat takvog djelovanja kod određenog dijela javnosti stvara nepovjerenje prema medijima. Osobito zanimljiv medijski fenomen odražava se u izvanrednim okolnostima, kao što je primjerice pandemija, koja je s razlogom preplavila sve svjetske, pa tako i lokalne medije. Međutim, kako su mediji, konkretno internetski portali, izvještavali o toj temi, kakva je perpecija čitatelja o načinu izvještavanja i prepoznaju li dezinformacija, neka su od problemskih pitanja ovoga rada.

\section{Internetski portali kao izvor informiranja}

Internet je u 21. stoljeću postao najveći izvor informacija, ali i platforma za digitalnu interakciju. Njime se služe skoro sve dobne skupine te se koristi u različite svrhe. Može mu se pristupiti putem raznih uređaja, kao što su računalo, mobitel, tablet, televizor, sat i ostali digitalni uređaji. „Internet je nastao sasvim spontano krajem 20. stoljeća kako bi se njime tada mogli služiti znanstvenici vojnoindustrijskih kompleksa za razmjenu podataka diljem SAD-a“ (Tesla.carnet.hr, n.p.). Teško je bilo naslutiti da će u kratkom vremenu postati multimedijalna globalna mreža koja će ispunjavati svakodnevicu gotovo svakog pojedinca diljem svijeta. Razvojem interneta i digitalizacije rasle su i njegove mogućnosti. Danas internetski korisnik može doprijeti do svih sadržaja koji bi ga mogli zanimati u privatnom i poslovnom području, brzo i lako u bilo kojem trenutku. Tu su mogućnost, pored mnogih drugih grana, iskoristili i mediji. Internet je značajno utjecao na medije i time je pokrenuta potpuno nova dimenzija širenja vijesti. Do tog su trenutka glavnu riječ imali 
tisak i televizija, što gube pojavom novih medija. „Tri ključne specifičnosti online u odnosu na offline medije: hipertekstualnost, multimedijalnost i interaktivnost“ (Kuduzović, 2016, str. 583). Karakteristike digitalnih medija su laka dostupnost, veći i brži protok informacija, velik broj audiovizualnih sadržaja te mogućnost komentiranja i dijeljenja (uključivanje javnosti). Sve to na kraju vodi puno većoj slobodi u digitalnoj medijskoj zajednici. Kao što Brautović (2011) navodi, u online medijima ne postoji ograničenje vremena i prostora, što donosi mnoge pogodnosti, ali i nedostatke. Agencija za istraživanje IPSOS je u ožujku 2019. godine za portal 24sata.hr provela istraživanje o medijskim navikama u Hrvatskoj. Prema rezultatima istraživanja, uočeno je kako se praćenjem medija zadovoljava potreba za informiranjem i razumijevanjem važnih događaja koji imaju utjecaj na život. Upravo zbog dostupnosti i brzine interneta, on je postao medij na kojeg se mnogi, bez obzira na godine, oslanjaju u raznim situacijama, u različito vrijeme i na različitim mjestima. Internet je istaknut kao medij koji se najčešće koristi, a informacije do kojih se dolazi na taj način smatraju se jedinstvenim i pouzdanijim od onih u drugim medijima. Televizija i dalje, uz internet, predstavlja medij s najvećim dosegom. Prema istraživanju, najveće praćenje televizijskog programa odvija se u večernjim satima. Radio je medij koji mnogi koriste tijekom vožnje, uz maksimalni doseg tijekom prijepodnevnih sati. Za tiskane medije, koji imaju manji doseg od onih elektroničkih, karakteristično je što se najviše koriste u javnim prostorima poput kafića, restorana i čekaonica. Bez obzira na dob i medij, za čitanje sadržaja dnevnih novina dominiraju informativni portali (24sata.hr, 2019).

„Internet dobiva sve više na važnosti u našem svakodnevnom životu kada su u pitanju informiranje, edukacija i zabava. Koristi se u široku rasponu situacija i svakome dijelu dana.“ (Skoko, Vrdoljak, 2018, str. 80) Kao i tradicionalni mediji, internetski portali pokrivaju teme iz svih rubrika i objavljuju raznolike sadržaje. Kada je riječ o medijima koji postoje i u drugim oblicima osim u formi portala, nerijetko se te informacije kopiraju i prilagođavaju alatu. Također, na hrvatskim se portalima često može pronaći sadržaj koji je preuzet sa stranih portala i prilagođen hrvatskoj publici. Ipak, valja napomenuti kako je teško utvrditi stvarni utjecaj internetskih medija. Skoko i Vrdoljak (2018) dalje ističu kako se metrika kojom se danas koriste ponajviše služi u oglašavanju te da se njome ne mogu najtočnije mjeriti stvarni dosezi internetskih portala i ostalih medija, a naročito kada je riječ o vjerodostojnosti. „Kod televizije smo znali koliko je ljudi u ukupnoj populaciji vidjelo oglas (ili određeni sadržaj), odnosno, preciznije, koliko je ljudi imalo priliku vidjeti određeni oglas (ili sadržaj)“, navode 
Skoko i Vrdoljak (2018, str. 83-84) te ističu kako nikad nisu točno znali koliko je ljudi zapravo vidjelo taj sadržaj i kako su ga doživjeli, iako su se koristile (i još se koriste) relativno dobre statističke metode na osnovi kojih se određivala gledanost. Ipak, i te statističke metode neusporedivo su lošije, pa i zastarjele, za digitalno doba u kojem se može i treba imati jako preciznu statistiku. Kod tiska se znalo koliko je ljudi kupilo novinu. Vlasnici tiskanih medija uvjeravali su da je konzumacija svakoga pojedinog sadržaja jednaka statistici za paket, što nije uvijek točno jer se novine čitaju selektivno i svakomu sadržaju ne posvećuje se podjednaka pozornost. Radio i vanjsko oglašavanje nisu imali ni približno dobre statistike, već su se njihovi dosezi mjerili kroz anketna istraživanja koja su pokušavala utvrditi „broj očiju“ koje su vidjele oglas, odnosno „broj ušiju“ u slučaju radija. Internet donosi veliku promjenu. Iako se i dalje gleda, a ponegdje se i prodaje „broj očiju“, internet se ponajprije razlikovao mjerenjem akcije. Akcija, a ne potencijalni pogled, je ono što je omogućilo internetsku revoluciju u oglašavanju i rast kompanija poput Googlea i Facebooka. Google i Facebook preskočili su poglede, a naplaćivali su samo akciju, odnosno situaciju kada posjetitelj klikne na određeni oglas, što im je bila potvrda da je primatelj vidio i konzumirao određeni oglasni sadržaj, ističu Skoko i Vrdoljak (2018). Može se zaključiti kako je trenutno teško utvrditi stvarni doseg internetskih informacija, ali i onih drugih medija, koliko je zapravo ljudi pročitalo neki sadržaj ili njegov dio, koliko se dugo korisnik zaista zadržao na njemu i kako ga je percipirao te koje su sociodemografske karakteristike korisnika. Ipak, digitalni mediji omogućili su portalima jednu značajnu prednost, a to je dijeljenje sadržaja. Gotovo da ne postoji informativni portal koji nema stranicu na društvenim mrežama. Bautović (2011 prema Volarević, Bebić, 2013, str. 63) spominje Noru Paul s instituta The Poynter Institute koja razlikuje dvije osnovne vrste novinarskih izvora na internetu: primarne i sekundarne. U prvu skupinu izvora idu mrežni izvori koji omogućuju kontakte s osobama, odnosno omogućuju davanje komentara, diskusiju i izražavanje stavova. U tu se skupinu ubrajaju elektronička pošta, news-grupe, diskusijske liste, forumi, chat, online društvene mreže, blogovi, online baze podataka. S druge strane, u skupinu sekundarnih izvora ubrajaju se mrežne stranice koje sadrže članke, izvještaje, studije. Društvene su mreže svojim mogućnostima značajno promijenile način komunikacije. Prema podacima s internetske stranice Internet Live Stats, trenutno je u svijetu preko 4,5 milijarde internetskih korisnika, dok se njih više od 3,8 milijardi služi društvenim mrežama (Internetlivestats.com, 2021). Uzimajući u obzir taj podatak, jasno je zašto je najveće žarište internetskih portala upravo 
na društvenim mrežama. Portali mogu objaviti sadržaj u iznimno kratkom vremenu i već u sljedećem trenutku taj je isti sadržaj podijeljen još nebrojeno puta, a sve to zahvaljujući korisnicima. Portali objavljuju sadržaje gotovo iz minute u minutu, a korisnike dijeli samo jedan klik do pristupa željenim informacijama, koje osim dijeljenja, mogu komentirati i reagirati na dobiveni sadržaj. Na taj način mediji automatski dobivaju povratne informacije o objavljenome i mogu lakše procijeniti kakav je sadržaj najbolje prihvaćen u javnosti. Upravo to velika je prednost internetskih portala. Uz sve to, portalima i dalje najviše znači broj klikova. Stoga portali sve više objavljuju sadržaje s naglaskom na zanimljivosti i zabavu, dok su vjerodostojnost i obavještajnost tih objava upitne. Nerijetko se na društvenim mrežama pronalaze komentari u kojima se kritiziraju portali s obzirom na vrstu objavljenih sadržaja, ali treba uzeti u obzir da se sadržaj stvara prema interesima publike. Pristupi li se iz tog kuta, može se zaključiti da je javnost najviše odgovorna za porast prisutnosti takvih sadržaja. Neupitno je da su internetski portali i digitalni mediji prvi kada je riječ o učestalosti korištenja, no ujedno je sigurno i da su mediji postali oblikovatelji javnog mišljenja te da se koriste tom činjenicom. Jurčić (2017, str. 133) ističe kako se stvaraju upravo takve vijesti koje potiču na klikanje, reagiranje i dijeljenje, koje više utječu na emocije, pa na taj način i nastaju indicije za medijske manipulacije, kao što su: kraće teme su traženje, lakše ih je prenijeti nego dulje i složenije informacije; površnost je lakša od dubine sadržaja; bizarno privlači više pozornosti od uobičajenog; preko medija šalju se poruke o potrošnji kao primarnoj ljudskoj potrebi. Takva praksa postupno je doprinijela većem nepovjerenju u medije zbog pojave širenja lažnih vijesti.

\section{Pojava İ fenomen lažnih vijestí u medijima}

Pandemija je bila idealna podloga za stvaranje i širenje lažnih vijesti, u potpunosti je promijenila medijsku sliku pa gotovo da nije postojao objavljeni sadržaj koji nije bio vezan uz koronavirus. Povremeno su objavljivani senzacionalistički naslovi koji su se temeljili na zastrašivanju, naslovi koji su završavali upitnikom i slično, a kod brojnih ponuđenih informacija izostajao je izvor te su bile neprovjerljive. Lažne vijesti postale su nezaobilazni dio suvremenih medija, a mogu se uklopiti u sve vrste sadržaja. Osobito su prisutne kada je riječ o novim pojavama koje zanimaju širu javnost, o nedovoljno poznatim temama, kada 
se želi manipulirati javnošću (najčešće u političkim situacijama), kada je u javnosti prisutan strah te sličnim okolnostima. Iako mnogi fenomen lažnih vijesti povezuju s pojavom digitalnih medija i društvenih mreža, razni oblici širenja dezinformacija prisutni su od trenutka kada je Gutenberg izumio tiskarski stroj 1439. godine (McIntyre, 2018). Jedna od najpoznatijih priča o širenju dezinformacija putem medija zasigurno je ona o izvanzemaljcima iz 1938. godine. Mreža Columbia Broadcasting emitirala je adaptaciju romana iz 1898. godine Rat svjetova. Prve dvije trećine priče emitirane su na radiju kao niz kratkih vijesti, a učinak je bio toliko stvaran da je kod brojnih slušatelja izazvao paniku jer su smatrali da se zaista dogodila invazija izvanzemaljaca. Prije kraja emisije liječnici, medicinske sestre, vojnici i mornari prijavili su se za dežurstvo, spremni na borbu protiv Marsovca. Policijske postaje širom zemlje odgovorile su na tisuće poziva. Novinari, čuvši za invaziju, požurili su s pripremom posebnih izdanja. Producenti emisije nespremno su dočekali takvu reakciju publike jer nisu mislili da će netko povjerovati da je invazija stvarna (The Social Historian, 2019). Godine 1983. zapadnonjemački časopis Stern platio je 3,8 milijuna dolara za kolekciju od 60 ručno napisanih bilježnica za koje su urednici vjerovali da su dnevnici Adolfa Hitlera. Prava na serijsko objavljivanje prodana su raznim međunarodnim časopisima, uključujući The Sunday Times, koji su od svojega neovisnog direktora, oksfordskog povjesničara Hugha Trevor-Ropera, zatražili autentičnost dnevnika. Učinio je to, proglasivši ih istinitim. Međutim, na konferenciji za novinare, Trevor-Roper brzo je izrazio sumnju u to da su dnevnici autentični, zajedno s drugim povjesničarima. U roku od dva tjedna nakon njihova objavljivanja, Državni arhiv Njemačke proglasio ih je lažnim nakon što je otkriveno da rukopis nije samo bio nedosljedan, već su i dnevnici pisani na modernom papiru obojenom čajem, koji samo izgleda staro. Nakon nereda na Broadwater Farmu 1985. godine, u kojem je ubijen policajac PC Keith Blakelock, policija i tisak organizirali su šokantnu kampanju protiv osumnjičenog Winstona Silcotta, prikazujući ga kao „zvijer iz Broadwater Farma“. Osuđen s gotovo nikakvim dokazima, pušten je tri godine kasnije nakon što se pokazalo da je policija krivotvorila bilješke $s$ intervjua. U jeku rata u Iraku 2003. godine, članci o nepostojećem oružju za masovno uništenje Sadama Husseina punili su novinske stranice širom svijeta (DW.com, n.p.). S početkom 21. stoljeća, razlozi objavljivanja i širenja lažnih vijesti uglavnom su politički. U prosincu 2016. godine prvi tweetovi Donalda Trumpa na digitalnoj platformi Twitter sadržavali su fraze poput fake news. Tijekom sljedeće godine, koristio je tu frazu preko 150 puta. Upravo 2016. godinu, 
povezanu s američkim predsjedničkim izborima, mnogi navode kao početak novog i najvećeg vala širenja lažnih vijesti. Nakon naglog procvata lažnih vijesti, pokrenuta je istraga kada je primijećen veći broj izmišljenih priča o Hillary Clinton na različitim internetskim stranicama prije samih izbora. Ispostavilo se da su sve stranice registrirane s istoga mjesta, a radilo se o makedonskom gradu Velesu. Otkriveno je više stotina stranica koje su sadržavale brojne lažne vijesti kojima se podupirala kandidatura Donalda Trumpa. Stranice su pokrenuli i vodili makedonski tinejdžeri koji su tim pričama postigli veliki uspjeh na društvenim mrežama. Kasnije je utvrđeno kako tinejdžeri nisu samostalno i spontano pokrenuli priču, nego je vjerojatno da su u „kampanju“ bile uključene razne utjecajne osobe iz Amerike (Bbc.com, n.p.). Pojam lažnih vijesti najčešće se definira kao “namjerno i tendenciozno iznošenje lažnih ili obmanjujućih tvrdnji s ciljem utjecaja i manipuliranja kognitivnim procesima ciljane publike” (Gelfert, 2018, Lazer i sur., 2018 prema Biloš, 2019). Nastupilo je vrijeme $u$ kojemu je gotovo nemoguće da korisnik društvenih mreža tijekom dana ne naiđe na neku vrstu lažne vijesti. Budući da se na platformama društvenih mreža sadržaji mogu nekontrolirano dijeliti, a svaki dodatni klik portalu daje veću vrijednost, upravo su one glavno žarište lažnih vijesti. Mogu se uklapati i koristiti u tematski raznovrsnim sadržajima te doprijeti do različitih skupina ljudi. Sadržaji i naslovi takvih vijesti oblikovani su s ciljem privlačenja pozornosti. Često primamljiv naslov obećava mnogo, a u samom tekstu korisnik ne uspijeva pronaći valjane informacije. I korisnike koji smatraju kako su otporni na senzacionalističke naslove i vijesti nerijetko uspiju zavarati, pa korisnik barem klikne i pokrene stranicu, što je i bio cilj internetskog portala. To dokazuje činjenica da su donedavno takve vijesti pretežito objavljivali portali koji su okarakterizirani kao „žuti tisak“, no danas gotovo da i ne postoji razlika. Upravo su zbog toga Skoko i Vrdoljak (2018, str. 86) uočili potrebu za promjenom načina korištenja metrike u medijima te naglasili da se "metrika mora okrenuti prema mjerenju pozornosti (engl. attention) te praćenju referenciranja na određeni sadržaj uz prepoznavanje korisnika. Ipak, i dalje smo fokusirani na stara mjerenja, pa se i mediji na našem tržištu uglavnom trude imati samo što više posjetitelja. U prvome je planu broj posjeta jedinstvena korisnika u mjesec dana te broj ukupno pregledanih stranica. Iako se prati sociodemografija korisnika, dok god imamo ovakvu metriku, ona će gurati medije prema jednostavnu sadržaju (često senzacionalnističkomu) koji samo privlači klikove. Metrika koja bi uzimala u obzir attention te bolje znala tko je korisnik na kojem sadržaju, vratila bi mogućnost da uopće dođe do održive 
ekonomije kvalitetna sadržaja." Dejanović je u Priručniku za provjeru informacija iz medija (2020, str. 20) prezentirao nekoliko oblika lažnih vijesti. Kao prvi oblik navodi loše vijesti. Jednostavno rečeno to su nenamjerno lažne vijesti koje nastaju zbog lošeg rada autora. Sljedeći oblik koji navodi pojavljuje se isključivo na digitalnim mrežama, a to je clickbait. „Riječ je o tekstovima koji mogu i ne moraju sadržavati stvarnu vijest, a čiji su naslovi napisani tako da u čitatelju izazovu intrigu i želju da pročita članak: 'Poznata osoba je učinila nešto, a onda se dogodilo ovo', 'Nije ni sanjao da će mu se ovo dogoditi', 'Ovakvu reakciju nije očekivao'... - naslovi su koji daju naslutiti da je u tekstu opisan događaj koji bi čitatelj mogao smatrati emocionalno uzbudljivim (ili jednostavno tračerskim), a koji to uopće ne moraju biti. Cilj ovakve vijesti jest zarada na reklamama koje se čitatelju prikažu dok pokušava otkriti što se to tako uzbudljivo dogodilo, ali i stvoriti priliku nakladniku i trećim osobama da prikupe određene informacije o samom čitatelju, najčešće radi dalje monetizacije njegovih navika." Dejanović dalje spominje oblike koji su najčešće bili prisutni tijekom prošlosti, a i danas ih se nerijetko može pronaći u medijima. Naime, "satirični i humoristični sadržaji, ako su dobro sročeni, mogu u čitatelju izazvati zabunu i poneke ljude uvjeriti kako je ono što u njima piše istinito. Satirični sadržaji sami po sebi posve su benigne naravi, ali ponekad mogu biti shvaćeni ozbiljno i sami od sebe započeti online životni ciklus lažne vijesti.“" (Dejanović, 2020, str. 21) Razlog je tomu situacija u svijetu i Hrvatskoj s epidemijom koronavirusa i potresom u Zagrebu. Obje su pojave potresle javnost svojim snažnim posljedicama. Iako su to grozne, nesretne pojave, idealna su podloga za širenje lažnih vijesti. Riječ je o pojavama koje se tiču široke mase, javnost je u strahu i javljaju se neprilike s kojima se ljudi ne znaju nositi. Popularna metoda koju spominje jest zastrašivanje. Njime se izaziva jaka emocionalna reakcija čitatelja i time gotovo jamči širenje vijesti. Dejanović (2020, str. 23) ističe kako se "najčešće zastrašuje osobnim zdravljem i osobnom sigurnošću čitatelja, serviranjem veće ili manje količine zastrašujućih materijala koji mogu, ali ne moraju biti istiniti, iskrivljeni radi boljeg učinka ili namjerno pogrešno interpretirani kako bi na kraju lažne vijesti čitatelju bilo ponuđeno spasonosno rješenje.” U stvarnosti to je samo jedan od načina kako autor određene lažne vijesti namjerava navesti čitatelja na kupnju nekog lijeka, usvajanje određenog svjetonazora, itd. Ipak, zastrašivanje je moguće prepoznati po "količini loših stvari što ih članak navodi, koje se mogu dogoditi čitatelju ili su se dogodile u blizini čitatelja. Ako vijest pritom sadrži i informaciju o spasonosnom rješenju ili poziv na akciju, možemo zaključiti da je riječ o zastrašivanju.“ 
Na kraju, tu su razne teorije zavjere i dezinformacije koje su u današnje vrijeme sve prisutnije, a vjerna im je publika sve brojnija. Teorije zavjere koje su prisutne u 2020. godini one su o izmišljanju epidemije koronavirusa, o utjecaju $5 \mathrm{G}$ mreža, o ravnoj zemlji, o razlozima migrantske krize i ostalo. Iako su neke od njih očito pogrešne, mnogi i dalje pronalaze razloga vjerovati u njih i time potiču dodatno širenje lažnih vijesti. Dezinformacije nisu poseban oblik vijesti, nego najčešće ključan dio spomenutih kategorija. Iako je kreiranje i širenje lažnih vijesti zapravo kazneno djelo, još uvijek je teško regulirati takve postupke. Suzbijanje lažnih vijesti trenutno je predstavljeno kao jedan od prioriteta Europske komisije koja navodi sljedeća temeljna načela i ciljeve koji bi trebali voditi rješavanju pitanja dezinformacija: poboljšanje transparentnosti, promicanje raznolikosti informacija, poticanje vjerodostojnosti informacija, podizanje svijesti, jačanje medijske pismenosti, široka uključenost dionika i suradnja javnih tijela i ostalih povezanih čimbenika (Dokler, 2018). Uz to, Tijana Vukić pojašanjava kako se lažne vijesti zasad međunarodno istražuju s različitih stajališta - sadržaja visokoškolskih kurikula, stavova studenata, novinarstva i medijskih studija, novinarske prakse, medijske publike, itd. Autorica navodi kako se u rješavanju problema obrazovanja novinara i lažnih vijesti mogu izdvojiti tri strujanja te pojašanjava kako se prvo odnosi na sustavnu formalnu ili dodatnu edukaciju o medijskoj I informacijskoj pismenosti. Sljedeće se odnosi na razne promjene vezane uz sustav visokog obrazovanja za obrazovanje novinara (najčešće su sugestije vezane uz studijski program), ali bez konkretnih prijedloga za njegovu rekonstrukciju ili nadogradnju, dok posljednje zagovara dodatno stručno obrazovanje zaposlenih novinara (Vukić, 2020).

\section{Istraživački ciljeví, pitanja î metodologija}

U sklopu emiprijskog istraživanja provedeno je anketno istraživanje kako bi se prikupile informacije o mišljenju i stavovima ispitanika. Predmet istraživanja bio je fokusiran na izvještavanje najčitanijih hrvatskih portala o koronavirusu tijekom epidemije. Provedeno je primarno istraživanje putem CAWI metode prikupljanja podataka. Anketni upitnik bio je anoniman i namijenjen svima koji čitaju hrvatske portale. Ispitanicima je upitnik proslijeđen putem društvenih mreža. Uzorak je činilo 108 ispitanika. Anketiranje se provodilo u razdoblju od 4. do 11. lipnja 2020. godine. Ciljevi istraživanja bili su odrediti navike ispitanika na internetu, definirati percepciju čitatelja o hrvatskim portalima te definirati 
percepciju čitatelja o medijskom izvještavanju tri najčitanija hrvatska portala tijekom epidemije koronavirusa. Sukladno postavljenim ciljevima, oblikovana su sljedeća istraživačka pitanja i hipoteze:

- IP1: Koliko čitatelji vjeruju hrvatskim portalima?

- IP2: Jesu li internetski portali vjerodostojni izvor informacija?

- IP3: Kakav su utjecaj Stožer i mediji imali na čitatelje?

- H1: Čitatelji pretežno vjeruju hrvatskim portalima.

- H2: Internetski portal vjerodostojni su izvor informiranja.

- H3: Krizni stožer i mediji imali su negativan utjecaj na čitatelje.

Upitnik je sadržavao 19 pitanja, odnosno 18 obaveznih zatvorenih pitanja i jedno neobavezno otvoreno pitanje. Prvi dio ankete služio je za segmentiranje ispitanika prema spolu, dobi, mjestu stanovanja i stupnju obrazovanja. Potom su ispitanici pitani o njihovim navikama i preferencijama na internetu vezano uz portale. Nadalje, ispitanici su pomoću Likertove skale izražavali svoje stavove o djelovanju Nacionalnog stožera civilne zaštite i utjecaju na njih prema onome što su doznali iz medija. S obzirom na to da su se vijesti širile brzo i nekontrolirano, postavljeno je pitanje o mišljenju o količini lažnih vijesti tijekom spomenutog razdoblja. Nakon toga uslijedilo je poglavlje u kojemu su navedena četiri naslova s različitih hrvatskih portala. Od ispitanika se tražilo da označe ili navedu emocije koje su pojedini od njih izazivali. Na kraju se od ispitanika tražila ukupna ocjena (od 1 do 5) koja bi, prema njihovom mišljenju, opisala kvalitetu izvještavanja hrvatskih portala o koronavirusu. Osim anketnog upitnika, provedena su dva dodatna kratka istraživanja najčitanijih hrvatskih informativnih portala čiji je rezultati u ovom radu ne prikazuju. Razlog je ograničeni uzorak koji se koristio za izradu završnog rad te nije bilo moguće na temelju analize donijeti znanstveno utemeljene zaključke. 


\section{Predstavljanje predmeta istraživanja}

Početkom 2020. godine svijet je zahvatila pandemija koronavirusa. Sve je započelo već krajem 2019. godine kada su se u Wuhanu u Kini pojavili prvi slučajevi zaraženih novootkrivenim virusom. Krajem siječnja Svjetska zdravstvena organizacija (WHO) proglasila je epidemiju koronavirusa javnozdravstvenom prijetnjom od međunarodnog značaja zbog brzine širenja epidemije i velikog broja nepoznanica vezanih uz nju. Vrlo brzo bolest se nekontrolirano proširila na cijeli svijet. Prvi slučaj zaraze u Republici Hrvatskoj zabilježen je 25. veljače 2020. U tom je trenutku u svijetu bilo već registrirano 80.134 oboljelih osoba te 2698 smrtnih slučajeva. Ubrzo su Svjetska zdravstvena organizacija i Europska unija podigle rizik od koronavirusa na vrlo visok i visok. WHO je 11. ožujka 2020. proglasio globalnu pandemiju zbog koronavirusa (Koronavirus.hr, 2020). Cijeli svijet suočio se s krizom koja je svima promijenila način života. Proširili su se panika i strah od neprijatelja o kojem se nije znalo mnogo. Diljem svijeta uvođene su restriktivne mjere kako bi se usporilo širenje virusa i smanjio broj oboljelih. U Hrvatskoj i okolnim zemljama su se nakon povoljnije situacije značajno ublažavale mjere. U lipnju se ponovno broj oboljelih osoba u jednom danu povećavao do brojki koje su bile aktualne tijekom vrhunca epidemije u zemlji. Trenutno je u svijetu gotovo 10 milijuna slučajeva, a korona je iza sebe ostavila skoro pola milijuna preminulih (Index.hr, 2021). Situacija je to u kojoj javnost zahtijeva upućenost i informacije u svakom trenutku. Medijski sadržaji preplavljeni su brojnim temama o koronavirusu, a u „moru“ informacija i histeriji koja je u početku vladala, moglo se naići na različite sadržaje. Krizni stožer i mediji koji su u početnom stadiju ulijevali sigurnost, s vremenom su, zbog razvoja situacije, počeli gubiti povjerenje javnosti. Upravo se zbog toga stvorila potreba za ispitivanjem javnosti o načinu izvještavanja tijekom epidemije koja je još uvijek aktualna.

\section{Analiza rezultata}

Općeniti cilj ovog istraživanja bio je ocijeniti zadovoljstvo čitatelja o izvještavanju hrvatskih portala na temu koronavirusa. Anketni upitnik ispunilo je 108 ispitanika pri čemu 75 posto žena i 25 posto muškaraca. Veći dio ispitanika spada u dobnu skupinu između $16 \mathrm{i}$ 25 godina (64,8\%), potom slijede oni između 26 i 39 godina (24,1\%), njih 9,3 posto između 40 i 55 godina, dok je samo dvoje ispitanika starije od 56 godina (1,9\%). Većina ispitanika navela je Zagreb (80\%) kao mjesto stanovanja, a u manjem postotku još su i Zadar, Turanj, 
Sv. Filip i Jakov, Benkovac, Medulin, Split, Dubrovnik i Križevci. Među ispitanicima brojčano prevladavaju oni s visokom stručnom spremom - VSS/VŠS (58,5\%), zatim je njih $28 \%$ sa srednjoškolskim obrazovanjem, a doktorat njih $12,1 \%$. Jedna osoba navela je da posjeduje samo osnovnoškolsko obrazovanje. Nakon segmentiranja ispitanika prema dobi, spolu, mjestu stanovanja i obrazovanju uslijedilo je nekoliko kratkih pitanja o navikama ispitanika pri korištenju interneta. Najveći dio ispitanika portale čita putem mobitela, a samo njih 5,6 posto za to koristi računalo. Rezultati su skoro izjednačeni kod pitanja oko načina pristupanja portalima. Od 108 ispitanika, 49 posto do objava dolazi putem društvenih mreža, a 49,1 posto direktnim upisivanjem u tražilicu. Dvoje ispitanika dodalo je opciju uporabe aplikacije. Usprkos tome što je na početku ankete naveden jasan naslov i napomena da je namijenjena samo onima koji čitaju hrvatske portale, na sljedeće je pitanje šest ispitanika odgovorilo negativno. Ispitanike se upitalo prate li portale od pojave koronavirusa $\mathrm{u} \mathrm{Hr}-$ vatskoj. Njih 55,6 posto odgovorilo je potvrdno, a 38,9 posto ispitanika čini to ponekad. U narednom su pitanju ispitanici mogli označiti portale koje najviše prate. Ponuđena je mogućnost višestrukog odgovora te opcija dodavanja vlastitog, nespomenutog portala.

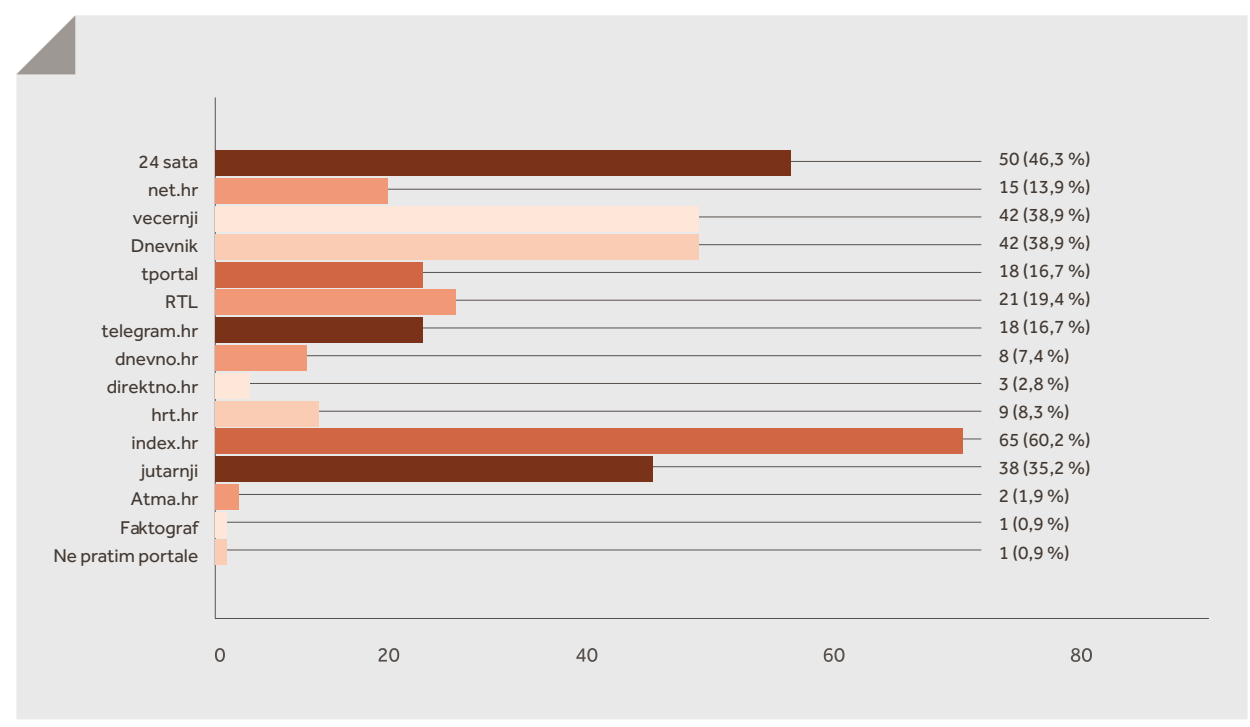

Grafikon 1. Odabir elektroničkih publikacija $(\mathrm{N}=108)$ 
Iz rezultata je vidljivo da se najviše prati elektronička publikacija Index.hr, a slijedi portal 24Sata te Večernji.hr i Dnevnik.hr koji imaju izjednačene rezultate. Ostali su portali, izuzev Jutarnjeg.hr, prikupili značajno manji broj glasova, što pokazuje da su najviše praćeni portali izgradili reputaciju te doista imaju određenu prednost na internetskom medijskom tržištu. Portali koje su ispitanici sami nadodali su Atma.hr te Faktograf koji analizira objavljenje sadržaje i provjerava ih prema postavljenim činjenicama. Potom se, temeljem rezultata za prethodno pitanje, željelo istražiti postoji li određeni portal kojem ispitanici najviše vjeruju. Potvrdni odgovor na pitanje dalo je nešto više od 86 posto ispitanika. Rezultati su iznenađujuće pozitivni te se može zaključiti kako javnost uistinu čita portale i da preko njih žele biti pravodobno i vjerodostojno informirani. Ujedno su u stanju postaviti svoje kriterije i objasniti kome su i zašto odlučili vjerovati. Na to se nadovezalo i iduće otvoreno pitanje u kojemu su se željeli saznati razlozi zbog kojih ispitanici preferiraju određeni portal. Neki od najčešće navedenih razloga su: višegodišnja procjena, navika, neutralnost portala, neprisutnost senzacionalizma, relativna objektivnost, brzo izvještavanje, kvalitetan sadržaj, raznolika ponuda tekstova, točnost u informiranju, stručnost novinara, nepostojanost clickbait naslova, provjera činjenica prema znanstvenim kriterijima, pozitivno dosadašnje iskustvo, vjerodostojnost te općenito ukupno pozitivan dojam nakon višegodišnjeg čitateljskog iskustva. Zatim su ponuđene pojedine tvrdnje, a od ispitanika se tražilo da označe onu koja najviše odgovara njihovim navikama na internetu. Grafikon 2 prikazuje rezultate odgovora na to pitanje.

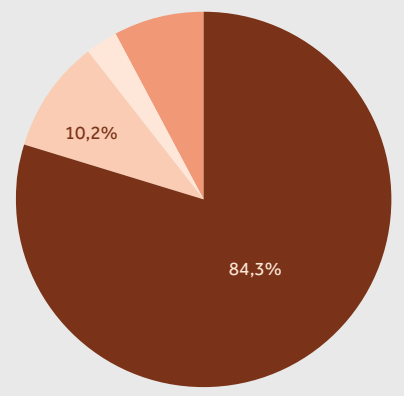

Kada naiđem na zanimljiv članak,

najčešće pročitam samo naslov bez otvaranja sadržaja

Kada naiđem na zanimljiv članak, najčešće pročitam naslovi otvorim njegov sadržaj

Kada naiđem na zanimljiv članak, najčešće pročitam samo naslov $i$ kom...

Ne pratim ništa vezano za korona virus jer ne postoji u mojoj stvarnosti ta kate...

Grafikon 2. Navike medijskih korisnika (N=108) 
U početku su ispitanicima ponuđena tri izbora, a dvoje ispitanika odlučilo je dodati četvrtu opciju kojom jasno ističu kako ne prate vijesti o koronavirusu jer smatraju da ta kategorija ne postoji u njihovoj stvarnosti. Taj se konkretni primjer može povezati s teorijama zavjere koje su prethodno spomenute $u$ radu. Tim se pitanjem htjelo utvrditi imaju li ispitanici naviku otvaranja i čitanja sadržaja članka nakon što su samo vidjeli određeni naslov. Budući da je u zadnje vrijeme veliki broj naslova oblikovan na senzacionalistički način koji privlači čitatelje na otvaranje sadržaja, rezultati ne začuđuju. Najveći dio ispitanika istaknuo je kako uz naslovnicu pročitaju i sam sadržaj članka, a 10,2 posto ispitanika ne otvarajući sadržaj odluči pročitati tek naslov i komentare na članak. Na pitanje o pridržavanju uputa Stožera ispitanici su odgovarali prema Likertovoj skali od 1 (nisam uopće) do 5 (apsolutno jesam).

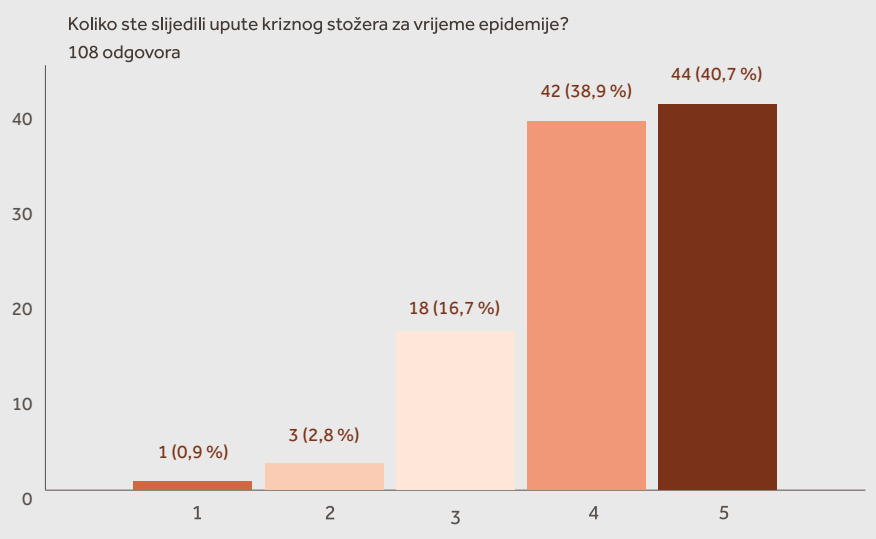

Grafikon 3. Pridržavanje uputa Stožera (N=108)

Iako se povjerenje prema Stožeru s vremenom očigledno postupno smanjivalo, većina je poštivala i prakticirala upute koje su medijima prenošene u javnosti. Prema rezultatima iz Grafikona 3 njih gotovo 80 posto vjerno je poštivalo mjere. Oko 4 posto ispitanika navelo je da nije poštivalo mjere, ali nepovjerenje u Stožer i medije nije nužno glavni razlog tome. Da takvo pozitivno ili negativno ponašanje nije nužno bilo povezano s povjerenjem u Stožer i medije, dokazuju rezultati prikazani na grafikonu 4. 


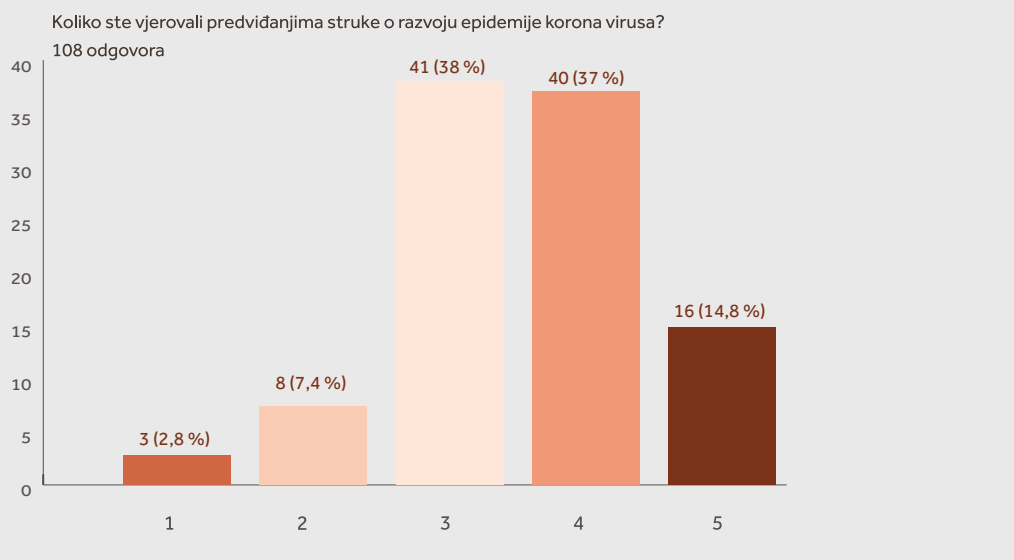

Grafikon 4. Povjerenje u Stožer i medije (N=108)

Treba napomenuti da su navedeni rezultati iz razdoblja kada se virus ponovno počeo učestalo javljati. U tijeku su bili i izbori pa je potrebno razmotriti i podatak da rezultati idu i ponešto u korist vladajućih. U tom je slučaju najviše ispitanika označilo broj tri, što predstavlja nekakvu sredinu, ali ne baš sjajnu sliku o vjerodostojnosti Stožera. Ipak, najveći postotak glasova dobile su ocjene tri, četiri i pet, a ocjenu jedan i dva označio je manji broj ispitanika, tj. njih 11. Prema mišljenu većine može se zaključiti kako je Stožer zadovoljavajuće obavljao svoj posao. Što se pak elektroničkih publikacija tiče, oni svoj dio posla očigledno nisu u potpunosti odgovorno odrađivali. Taj je zaključak donesen na temelju rezultata koji su prikazani na Grafikonu 5.

Prema vašem mišljenju, koliko je sadržaja objavljeno za koje smatrate da su uključivali

izmišljene ili lažne vijesti?

108 odgovora

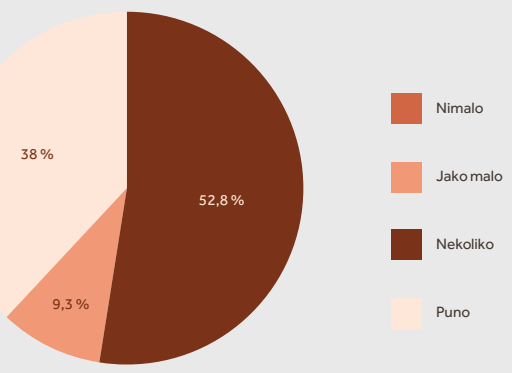

Grafikon 5. Lažne vijesti (N=108) 
Grafikon prikazuje pomalo zabrinjavajuću, no stvarnu situaciju. Medijski prostor u promatranom je vremenu bio preplavljen raznolikim sadržajem koji su brojni izvori objavljivali velikom brzinom. Budući da se radilo o novoj i nepoznatoj situaciji, epidemija je mnogim medijima služila kao savršeni alat uz čiju bi se pomoć lako širile razne neprovjerene informacije koje u ljudima nerijetko potiču snažne emocije, odnosno stvaraju dodatni nemir. Nitko od ispitanika nije smatrao da u medijskom prostoru za vrijeme epidemije nije uopće bilo lažnih vijesti, ali je zato njih skoro 10 posto smatralo da ih je bilo malo. Nešto više od polovice ispitanika smatra da se moglo naići na nekoliko lažnih vijesti, dok 38 posto ispitanika misli da je bilo prisutno puno izmišljenih informacija. U nastavku je bilo navedeno nekoliko naslova s različitih portala, a od ispitanika se tražilo da označe ili navedu emocije koje određeni naslov budi u njima.

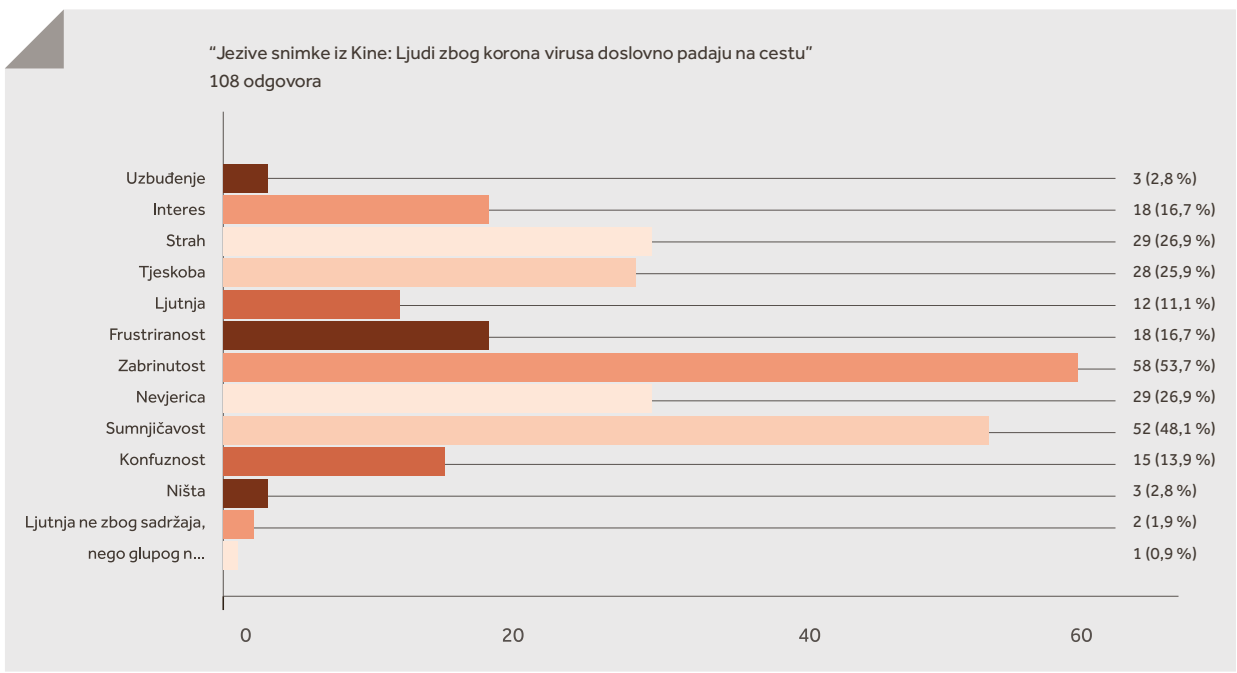

Grafikon 6. Emocije koje pobuđuju senzacionalistički naslovi (N=108)

Na Grafikonu 6 može se vidjeti kako na čitatelje djeluje tipičan primjer senzacionalističkog naslova. Takav naslov kod javnosti budi pretežito negativne emocije, poput zabrinutosti, sumnjičavosti, nevjerice, straha i tjeskobe. Time je pokazano kako ispitanici, osim osjećaja nelagode zbog karakteristika naslova, shvaćaju sadržaj kao nepovjerljiv, a kod nekih izaziva i ljutnju. 


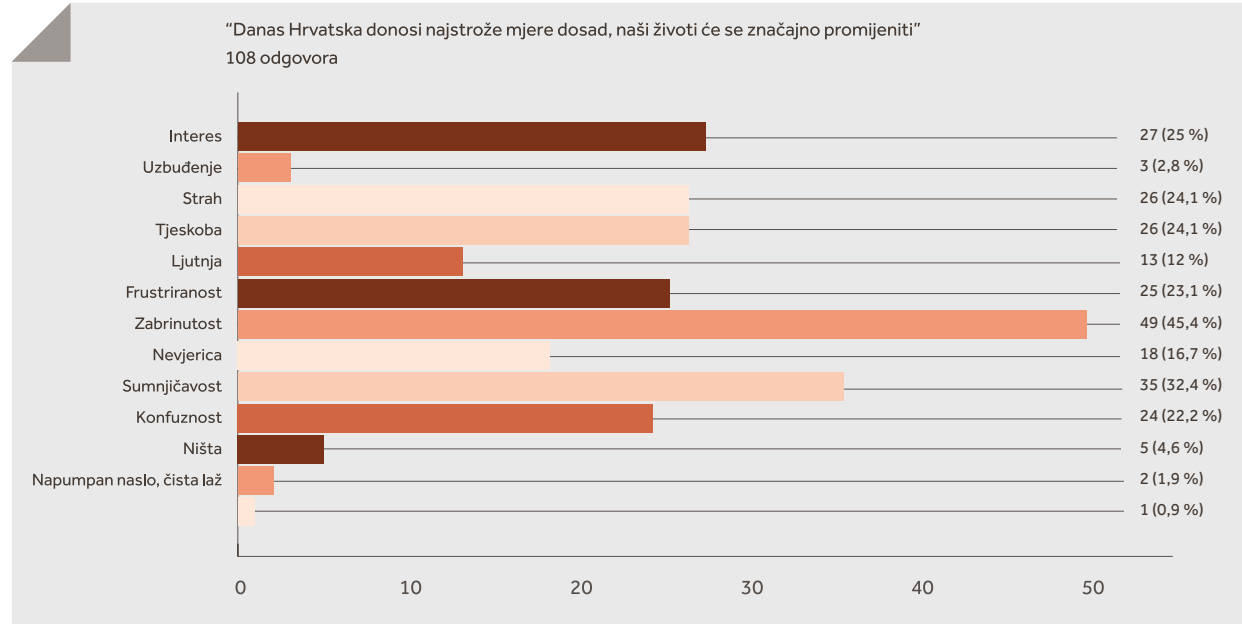

Grafikon 7. Pojava negativnih emocija kod odabranih naslova $(\mathrm{N}=108)$

Naslov s Grafikona 7. informativnog je karaktera, a oblikovan je tako da u čitatelju izazove neugodne osjećaje i privuče pozornost. Upravo su takve emocije ispitanici označili kao svoj odgovor. Gotovo svi ponuđeni odgovori dobili su značajan broj glasova, a najvećem broju ispitanika naslov je izazvao osjećaj zabrinutosti. Navedeni su i odgovori u kojem ispitanici jasno navode svoje saznanja o tome na koji su način kreirani naslovi te koja im je namjera.

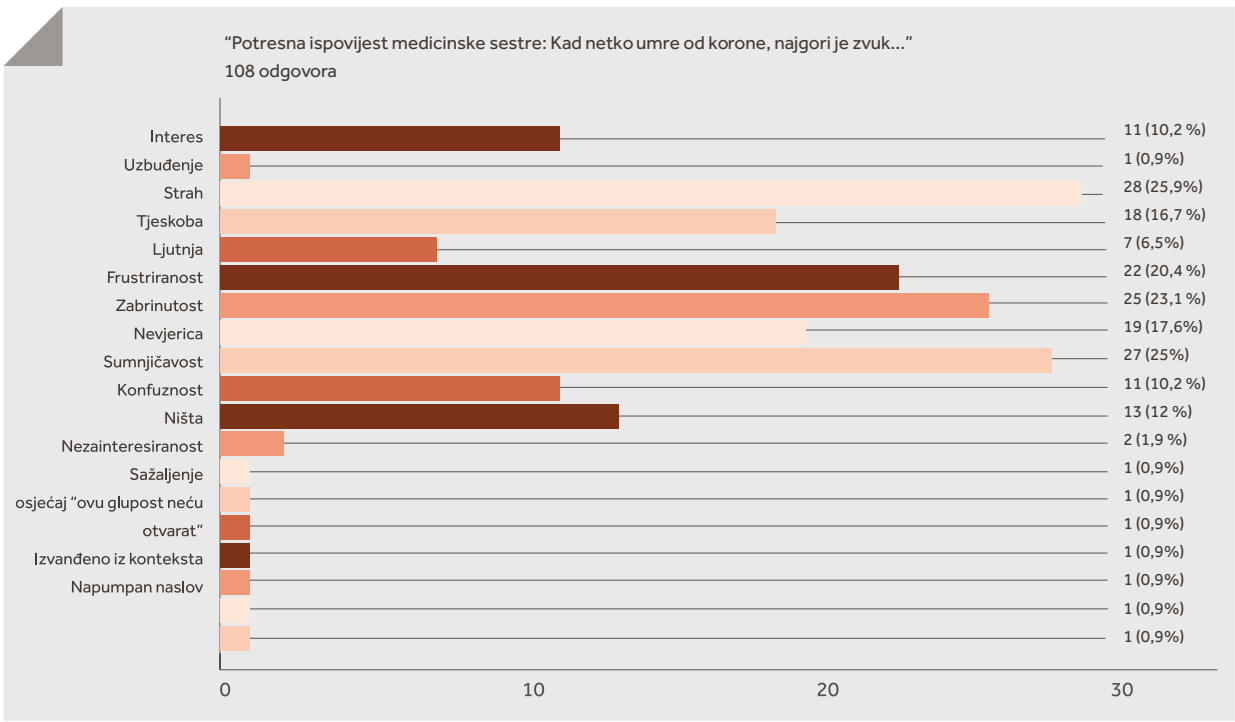

Grafikon 8. Emocije koje izazivaju clickbait naslovi (N=108) 
Na Grafikonu 8. može se vidjeti primjer koji najviše odaje dojam clickbait naslova. I ovoga puta prevladavaju iste negativne emocije, ali je više ispitanika dodalo vlastita mišljenja u kojima izražavaju svoje nezadovoljstvo i zgražanje nad obilježjima naslova. Takve naslove nerijetko se moglo vidjeti na stranicama različitih portala, što je ujedno i razlog zbog kojeg je određen broj osoba vjerovao u veliku prisutnost lažnih vijesti.

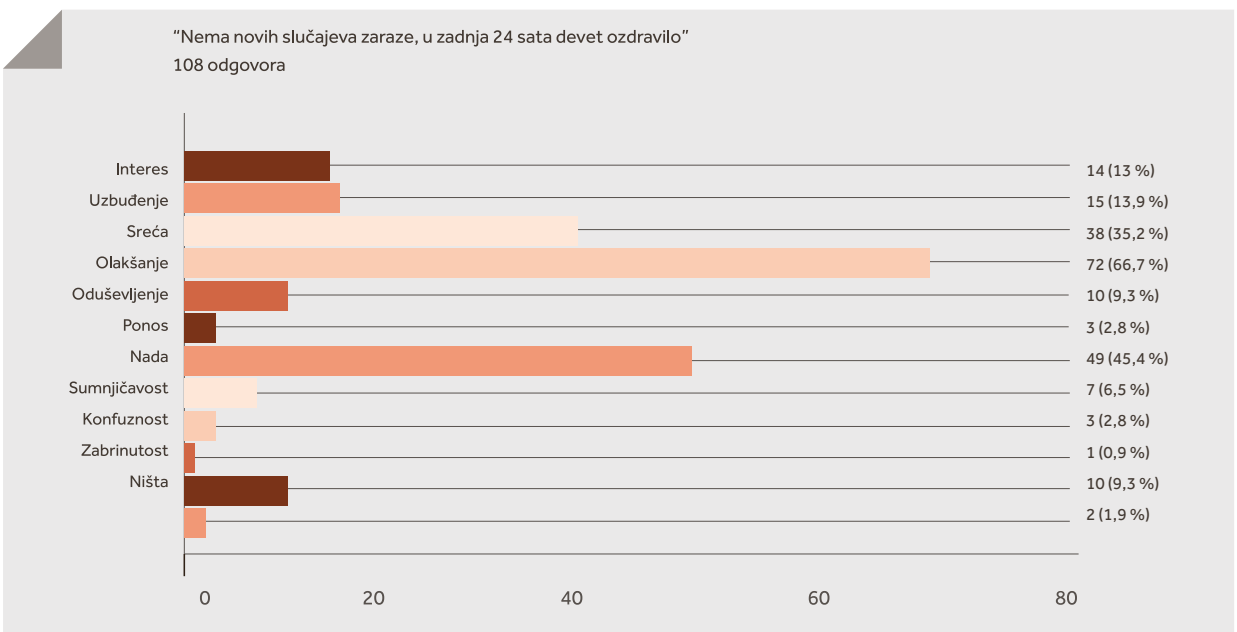

Grafikon 9. Emocije koje izazivaju pozitivne vijesti $(\mathrm{N}=108)$

Na kraju ovog dijela je ispitanicima dan primjer informativnog članka s pozitivnim vijestima. Rezultati iz Grafikona 9. pokazuju koliko je ljudima važna prisutnost takvih vijesti zbog emocija koje u njima mogu probuditi. Logično, ovoga su puta dominirale pozitivne emocije poput olakšanja, nade i sreće. Negativnih i neutralnih emocija gotovo da i nema, no određena količina sumnje i dalje je prisutna.

Na samom kraju ankete, od ispitanika se tražila ukupna ocjena kvalitete izvještavanja hrvatskih portala o koronavirusu, od 1 za opis „jako loše“, do 5 za ocjenu „odličan“. Rezultati su predstavljeni na Grafikonu 10. 


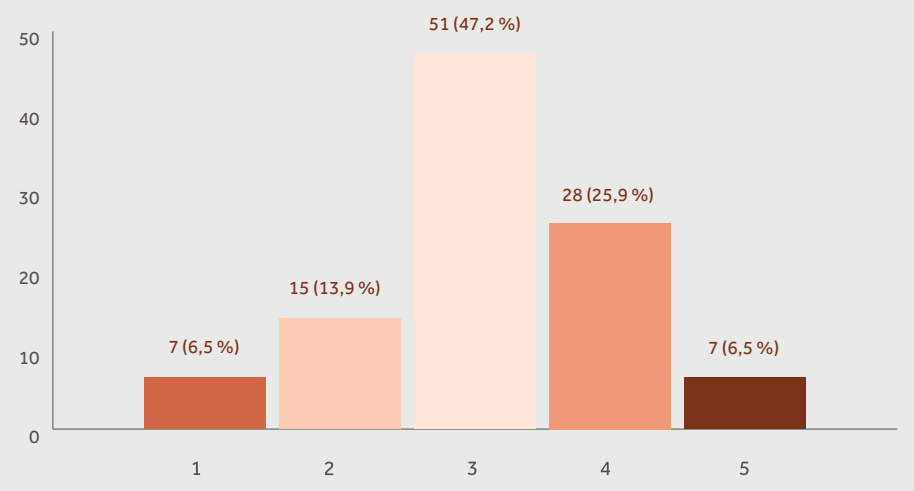

Grafikon 10. Ocjena kvalitete izvještavanja hrvatskih portal o koronavirusu (N=108)

Elektroničke publikacije i njihov način izvještavanja dobili su pozitivnu ocjenu. Većina ispitanika odlučila se za ocjenu tri. Najlošija i najbolja ocjena zaprimile su jednak, ali i najmanji broj odgovora (po 6,5\%).

\section{Zaključak}

U radu su prikazani teorijski aspekti medijskog izvještavanja i provedene različite metode istraživanja nastavno na postavljene ciljeve. U skladu s predmetom rada, definirana je pojava lažnih vijesti te su objašnjeni čimbenici internetskih portala kao izvora informiranja. Nakon uspješno provedenih anketnog istraživanja, dobiveni rezultati analizirani su i raspravljeni. Preostala dodatna istraživanja ne razmatraju se u ovom radu zbog ograničenog uzorka. Rezultati anketnog upitnika o navikama ispitanika na internetu i percepciji o hrvatskim portalima, odnosno izvještavanju tijekom epidemije koronavirusa pokazao je kako većina ispitanika prati portale od pojave koronavirusa u Hrvatskoj te da portalima najčešće pristupaju putem društvenih mreža ili direktnim upisivanjem u tražilicu svojih mobitela ili računala. U anketi su ispitanici većinom birali portale Index.hr, 24Sata.hr i Jutarnji.hr. Iako postoje mnogi portali koji ne privlače javnost, većina ispitanika ima određene portale kojima više vjeruje i to potkrepljuju čvrstim razlozima. Da su, prema rezultatima, određeni portali relevantni izvori informiranja utvrđuje se višegodišnjim čitateljskim iskustvom. Rezultati 
istraživanja upućuju na to da portal ne bi trebao izražavati pristranost prema nekoj osobi, stranci, pojavi i slično. Također, treba brzo, točno, raznoliko, kvalitetno i vjerodostojno izvještavati, a senzacionalističke naslove i slične forme izbjegavati. Iz navedenih rezultata može se zaključiti kako portali imaju još mnogo mjesta za popravak i poboljšanje ocjene. Neupitno je da brzina i količina sadržaja ne predstavljaju problem, odnosno time je javnost zadovoljna. Dakle, ona jednostavno mora biti pravodobno i redovito informirana. Kao problem javlja se prisutnost nebitnih i neistinitih sadržaja koji su svakim danom sve brojniji. Portalima zaradu predstavljaju klikovi čitatelja, pa se tako neprekidno iskorištava ljudska znatiželja i emocije. Sve dok ljudi nasjedaju na senzacionalističke naslove, to će ostati problem koji se ne rješava brzo i lako. S obzirom na to da se situacija oko koronavirusa $\mathrm{u}$ Hrvatskoj tijekom zadnjih pola godine naglo mijenjala, a taj proces još uvijek traje, bilo bi korisno provesti slične analize u bliskoj budućnosti kako bi se rezultati mogli usporediti. Pri tome treba naglasiti da je potrebna sveobuhvatnija analiza različitih medijskih objava, nego što je to bio slučaj s prikazanim ograničenim istraživanjem za potrebe izrade završnog rada. Vjerojatno je da bi mišljenja i reakcije na izvještavanja medija i odgovornih bila znatno drukčija. 


\section{Literatura}

- 24sata (2019). Medijske navike u Republici Hrvatskoj. Dostupno na: https://showcase.24sata.hr/2019_hosted_creatives/ medijske-navike-hr-2019.pdf, 3. lipnja 2020.

- Biloš, A. (2019). Izazovi internetskog informacijskog prostora: kako stanovnici republike Hrvatske doživljavaju problem lažnih vijesti. Ekonomski fakultet.

- Brautović, M. (2011). Online novinarstvo. Školska knjiga.

- Dejanović, R. (2020). Priručnik za provjeru informacija iz medija. Društvo za zaštitu novinarskih autorskih prava.

- Dokler, A. (2018). Dezinformacije na internetu jedan su od glavnih izazova Europske unije. Dostupno na: https://www. medijskapismenost.hr/dezinformacije-na-internetu-jedan-su-od-glavnih-izazova-europske-unije/, 12. lipnja 2020.

- DW.com (n.p.). Irački rat i laž kao opravdanje. Dostupno na: https://www.dw.com/hr/ira\%C4\%8Dki-rat-i-la\%C5\%BE-kaoopravdanie/a-43299008, 01. lipnja 2021.

- Grbelja, J., Sapunar, M. (1993). Novinarstvo - teorija i praksa. MGC.

- Hrnjić Kuduzović, Z. (2016). Hiperseksualnost, multimedijalnost i interkativnost vijesti na bosanskohercegovačkim web portalima Klix.com i Nezavisne.com. Medijski dijalozi, 24 (1), 579-595.

- Internet Live Stats (2021). Dostupno na: https://www.internetlivestats.com/, 4. lipnja 2020.

- Jurčić, D. (2017). Teorijske postavke o medijima - definicije, funkcije i utjecaj. Mostariensia, 21 (1), 127-136.

- McIntyre, L. (2018). Post-Truth. MIT Press.

- Skoko, B., Vrdoljak, N. (2018). Stvarni dosezi news portala - međuodnos čitanosti, vjerodostojnosti i utjecaja. Hum, 13 (19), $79-97$.

- Tesla.carnet.hr (n.p.). Nacionalni portal za učenje na daljinu - Nikola Tesla. Uvod u internet. Dostupno na: https://tesla. carnet.hr/mod/book/view.php?id=5428\&chapterid=883, 2. lipnja 2020.

- The Social Historian (2019). 10 Examples of Fake News from History. Dostupno na: https://www.thesocialhistorian.com/ fake-news/, 10. lipnja 2020.

- Vlainić, M. (2012). Kako hrvatske dnevne novine izvještavaju o djeci: analiza sadržaja Jutarnjeg i Večernjeg lista. Medijska istraživanja, 18 (1), 33-59.

- Volarević, M., Bebić, D. (2013). Društvene mreže kao izvor vijesti u najgledanijim središnjim informativnim emisijama u Hrvatskoj. Medijske studije, 4 (8), 60-74.

- Vukić, T. (2020). Journalism Education and Fake News: A Literature Review. Medijska istraživanja, 26 (2), 77-99. 


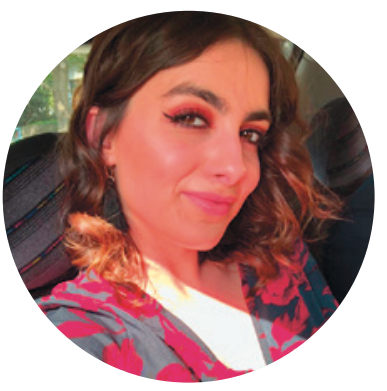

\section{Medina Bezinović}

Medina Bezinović je u Zagrebu završila osnovnu i srednju školu, a potom je diplomirala na studiju Odnosa s javnošću i medija na Sveučilištu Vern. Završni rad na temu "Analiza medijskog izvještavanja najčitanijih hrvatskih internetskih portala o koronavirusu" doticao se najaktualnije svjetske teme i njezinog utjecaja na medije i javnost, a usko je vezan uz ovaj rad.

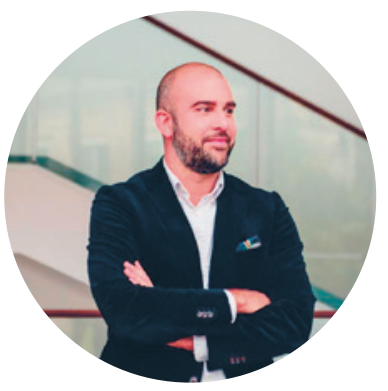

Krešimir Dabo

Krešimir Dabo je pročelnik Odjela za turizam i viši predavač na Edward Bernays University Collegeu. Tijekom preddiplomskog studija obrazovanje usmjerava na područje turističkog menadžmenta, dok na diplomskoj razini završava dva studija, jedan poslovnih komunikacija te drugi komunikologije i odnosa s javnošću. Doktorat je stekao u području društvenih znanosti, informacijsko-komunikacijskih znanosti. Predaje na nekoliko visokih učilišta na studijima turizma, komunikologije, odnosa s javnošću i medija. Profesionalnu karijeru počinje u području novinarstva, nastavlja u Odjelu za odnose s javnošću na RTL televiziji. U Anasamblu LADO vodi Odjel za odnose s javnošću i marketing, gdje zatim i obnaša dužnost ravnatelja.

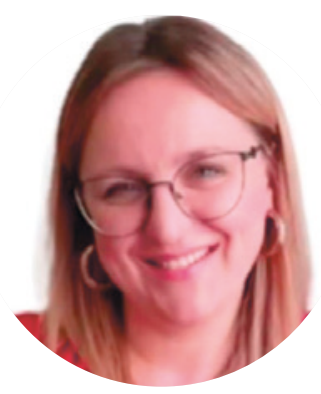

Helena Šimić

Helena Šimić je pročelnica Odjela za komunikacije i predavačica na Katedri za odnose s javnošću Edward Bernays University College. Diplomirala je novinarstvo na Hrvatskim studijima te stekla diplomu Londonske škole za odnose s javnošću. Karijeru je započela u vodećim agencijama za tržišno komuniciranje, a posljednjih deset godina radila je u Millenium promociji kao starija savjetnica i voditelj ključnih projekata za najveće domaće i međunarodne korporacije. Tvrtke L’Oreal, Sony, Johnson\&Johnson, Lufthansa, HP, McDonald's i brojne druge samo su neke od korporacija za koje je Helena savjetovala u komunikacijskim i Public Affairs aktivnosti te osmišljavala i provodila marketinške i komunikacijske projekte. Radom se usmjerila na strateško komuniciranje, odnose $\mathrm{s}$ medijima, product PR te korporativno i integrirano marketinško komuniciranje. Za NGO projekt „Jedan dan za čist okoliš” osvojila je i nagradu GrandPRix koju Hrvatska udruga za odnose $s$ javnošću svake godine dodjeljuje najuspješnijim komunikacijskim projektima. 